\title{
KOMPARATIF HUKUM ACARA PIDANA POSITIF DAN HUKUM ACARA PIDANA ISLAM (JINAYAH) ACEH DALAM PROSES PENYIDIKAN
}

\author{
Dahyul Daipon
}

IAIN Bukittinggi, Indonesia

Dayhuldaipon55@gmail.com

Received:20-01-2020; Revised:05-06-2020; Accepted: 11-06-2020;

ABSTRACT

This research aims to examine the differences of investigation process between the book of Procedural Criminal Law Constitution (KUHAP) or the Constitution number 8 of 1981 about Positive Procedural Criminal Law and Qanun Aceh number 7 of 2013 about Jinayat Procedural Law. The method used is the yuridis normative law research method. The Identification of problem is How is the investigation process based on the book of Procedural Criminal Law Constitution (KUHAP)? How is the investigation process based on Qonun Aceh number 7 of 2013 about Jinayat Procedural Law? What is the differences of investigation process based on Positive Procedural Criminal Law and Qanun Aceh number 7 of 2013 about Jinayat Procedural Law? The Result of analysis is Investigation process in KUHAP starts of the Investigation. Enforcement, Examination, Settlement, and Submition the case file to the public presecutor, it is process of investigation that written in the Constutition number 7 of 2013 about Jinayat Procedural Law. It mentions in verse 110 until 132. The differences of investigation process based on Positive Procedural Criminal Law and Qanun Aceh number 7 of 2013 about Jinayat Procedural Law are (1)related to paradigms of investigation description that different managed, (2) related to the investigator authority, and (3) related to the direct investigation of crime/jarimah.

Keywords: Investigation, Procedural Criminal Law and Qanun Aceh

\section{INTISARI}

Tujuan penelitian ini ialah untuk mengkaji perbedaan proses penyidikan antara Kitab UndangUndang Hukum Acara Pidana (KUHAP) atau Undang-Undang nomor 8 tahun 1981 tentang Hukum Acara Pidana Positif dengan Qonun Aceh Nomor 7 Tahun 2013 Tentang Hukum Acara Jinayat. Adapun metode yang digunakan ialah metode penelitian hukum normatif yuridis (yuridis normative). Rumusan masalahnya ialah Bagaimana Proses Penyidikan menurut Kitab UndangUndang Hukum Acara Pidana (KUHAP)? Bagaimana Proses Penyidikan menurut Qonun Aceh Nomor 7 Tahun 2013 Tentang Hukum Acara Jinayat? Apa Perbedaan Proses Penyidikan menurut Hukum Acara Pidana Positif dan Qonun Aceh Nomor 7 Tahun 2013 Tentang Hukum Acara Jinayat? Adapun hasil dan pembahasannya ialah Proses Penyidikan menurut KUHAP ialah mulai dari Penyelidikan. Penindakan, Pemeriksaan, Penyelesaian dan serta penyerahan berkas perkara kepada Jaksa Penuntut Umum, Bahwa proses Penyidikan yang tercatum di dalam Undang-undang Nomor 7 Tahun 2013 Tentang Hukum Acara Jinayat ialah tercantum di dalam Pasal 110 sampai dengan Pasal 132. Adapun terkait Perbedaan Proses Penyidikan menurut Hukum Acara Pidana Positif dan Qanun Aceh Nomor 7 Tahun 2013 Tentang Hukum Acara Jinayat ialah (1) terkait tentang paradigma penjelasan penyidikan yang diatur berbeda, (2) terkait tentang wewenang penyidik dan (3) terkait dengan penyidikan langsung tindak pidana/jarimah. 
Kata Kunci: Penyidikan, Hukum Acara Pidana dan Qonun Aceh

\section{A. Pendahuluan}

Pasca Era Kemerdekaan Republik Indonesia, negara berupaya dalam mencari bentuk sebagai negara yang berdaulat. Era ini menjadi paling penting bagi pembentukan hukum yang akan berlaku sampai dengan saat ini, termasuk di antaranya adalah dalam menentukan hukum yang akan berlaku di Indonesia. Sistem hukum yang dipergunakan suatu negara tentunya membawa banyak pengaruh terhadap hukum yang tumbuh dan berkembang di negara tersebut, tidak terkecuali dalam hukum pidana. Hukum pidana merupakan salah satu hukum positif khususnya pidana materil yang dalam hal ini diwakili oleh Kitab Undang-Undang Hukum Pidana (KUHPidana) mengingat hukum yang dianut di Indonesia adalah civil law system. ${ }^{l}$

Perkembangan ilmu pengetahuan dan teknologi membawa perubahan yang signifikan terhadap kondisi masyarakat. Berubahnya kondisi masyarakat, maka perubahan hukum akan menjadi keniscayaan. Oleh karena itu ada ungkapan ubi societas ibi ius, untuk menggambarkan makna hubungan antara perubahan sosial dan penemuan hukum. Ketika suatu masyarakat ada dan menciptakan hukum, maka pada saat masyarakat itu berubah, hukumpun akan berubah. Perubahan hukum dapat melalui dua bentuk, yakni masyarakat berubah terlebih dahulu, baru hukum datang mengesahkan perubahan itu (sifatnya bottom up), sedang bentuk lain yaitu hukum sebagai alat untuk mengubah ke arah yang lebih baik, sebagaimana teori law as a tool of sosial engineering dari Roscoe Pound (bersifat top down). Dalam hal perubahan terhadap hukum acara pidana, maka pada hakekatnya termasuk pada bentuk perubahan hukum pertama, yaitu yang bersifat bottom up. ${ }^{2}$

Untuk menegakkan dan mewujudkan kepastian hukum, tindakan aparatur penegak hukum secara formal harus ada pengaturannya, agar tindakannya tidak kontradiktif dengan undangundang. Artinya, tidak hanya mengacu kepada ketentuan hukum pidana materil, tetapi juga mengacu kepada hukum pidana formal, yang lazim disebut Hukum Acara Pidana. Hukum Acara Pidana merupakan hukum formal yang di dalamnya memuat ketentuan-ketentuan tentang bagaimana suatu proses beracara dalam rangka penegakan hukum pidana (hukum materiil). ${ }^{3}$

Undang-Undang Nomor 8 Tahun 1981 dianggap sebagai kodifikasi pertama produk pemerintah nasional. Walupun hanya satu peraturan perundang-undangan, namun undangundang ini disebut sebagai Kitab Undang-Undang Hukum Acara Pidana (KUHAP). Di dalam penjelasan umum KUHAP disebutkan bahwa dengan tujuan melindungi hak asasi manusia dan menjamin segala warga negara bersamaan kedudukannya di depan hukum dan pemerintahan itu dengan tidak ada kecualinya. ${ }^{4}$

Undang-Undang Nomor 8 Tahun 1981 tentang Hukum Acara Pidana (KUHAP) telah berlaku lebih dari seperempat abad, dalam kurun waktu itu banyak perubahan yang terjadi pada

${ }^{1}$ Tolib Effendi, Dasar-Dasar Hukum Acara Pidana Perkembangan dan Pembaharuan, (Malang: Setara Press, 2014), 1-2.

${ }^{2}$ Naskah Akademik Rancangan Undang-Undang Hukum Acara Pidana Tahun 2010, 1.

${ }^{3}$ Eddy O.S. hieariej, Pengantar Hukum Acara Pidana, (Jakarta: Modul I Materi Kuliah Prodi Hukum Universitas Terbuka), 1.

${ }^{4}$ Tolib Effendi, Dasar-Dasar Hukum, 2. 
kondisi umum baik di luar maupun dalam negeri yang membawa perubahan kondisi dan cara pandang masyarakat Indonesia. Perubahan itu banyak yang dipengaruhi oleh perkembangan ilmu pengetahuan di bidang demokrasi, Hak Asasi Manusia (HAM) serta perkembangan teknologi informasi dan komunikasi. Seiring dengan terjadinya perubahan tersebut, maka perlu untuk menyempurnakan beberapa ketentuan yang terkait, seperti: masalah perlindungan terhadap hak asasi tersangka/terdakwa, keseimbangan antara perlindungan harkat martabat tersangka/terdakwa dengan perlindungan saksi/korban serta kepentingan umum. ${ }^{5}$

R. Susiolo menyatakan bahwa hukum acara pidana itu merupakan hukum yang mengatur tentang cara bagaimana mempertahankan atau menyelenggarakan hukum pidana materiil, sehingga memperoleh keputusan hakim dan cara bagaimana isi putusan itu harus dilakukan. ${ }^{6}$ Berbeda dengan Van Bemmelem seperti yang dikutip Andi Hamzah, mengatakan bahwa pengertian Hukum Acara Pidana adalah ilmu yang mempelajari peraturan-peraturan yang diciptakan Negara, karena adanya dugaan terjadi pelanggaran Undang-Undang pidana yaitu sebagai berikut:

a. Negara melalui alat-alat menyidik kebenaran;

b. Sedapat mungkin penyidik pelaku perbuatan itu;

c. Mengambil tindakan-tindakan yang perlu guna menangkap si pembuat dan kalau perlu menahannya;

d. Mengumpulkan bahan-bahan bukti (bewijsmateriaal) yang telah diperoleh pada penyidikan kebenaran guna dilimpahkan kepada hakim dan membawa terdakwa ke depan hakim tersebut;

e. Hakim memberikan keputusan tenang terbukti tidaknya perbuatan yang dituduhkan kepada terdakwa dan untuk itu menjatuhkan pidana atau tindakan tata tertib;

f. Upaya hukum untuk melawan keputusan tersebut;

g. Akhirnya melaksanakan keputusan tentang pidana dan tindakan tata tertib. ${ }^{7}$

Berdasarkan penjelasan di atas, maka rumusan ketentuan Hukum Acara Pidana ialah menjabarkan seluruh proses peradilan di Indonesia. Adapun salah satu yang diatur di dalam KUHAP ialah adanya proses penyidikan. Proses ini menjadi kewenangan penuh dari pihak Kepolisian yang telah diberi kewenangan oleh Peraturan Perundang-Undangan. Sebagaimana yang diamanatkan oleh Pasal 1 angka 2 KUHAP bahwa "Penyidikan adalah serangkaian tindakan penyidik dalam hal dan menurut cara yang diatur dalam undang-undang, mencari dan mengumpulkan bukti yang dengan bukti itu membuat terang tentang tindak pidana yang terjadi dan guna menemukan tersangkanya".

Berbicara mengenai penyidikan tidak lain dari membicarakan masalah pengusutan kejahatan atau pelanggaran. Dimana yang berhak melakukannya ialah seorang Penyidik sebagaimana ditegaskan dalam Pasal 1 angka 1 KUHAP yaitu penyidik adalah pejabat polisi

\footnotetext{
${ }^{5}$ Eddy O.S. hieariej, Pengantar Hukum, 1.

${ }^{6} \mathrm{R}$ Soesilo, Hukum Acara Pidana (Prosedur Penyelesaian Perkara Pidana menurut KUHAP bagi penegak Hukum), (Jakarta: Politeria, 1982), 3.

${ }^{7}$ Andi Hamzah. Hukum Acara Pidana Indonesia, (Jakarta: Sinar Grafika, 2001), Edisi Revisi, 6.
} 
negara Republik Indonesia atau pejabat pegawai negeri sipil tertentu yang diberi kewenangan khusus oleh undang-undang untuk melakukan penyidik.

Rumusan KUHAP di atas, secara umum berlaku diseluruh wilayah yang ada di Indonesia, tetapi berbeda halnya dengan Provinsi Aceh yang notabenenya memakai sistem hukum syariah. Sebab rumusan di dalam Undang-Undang Nomor 8 tahun 1981 tentang Hukum Acara Pidana sebagai hukum formil yang berlaku di lingkungan peradilan umum, belum menampung sepenuhnya prinsip-prinsip hukum acara pidana Islam sesuai dengan kebutuhan Peradilan Syariat Islam. Karenanya kehadiran hukum acara jinayat merupakan kebutuhan mutlak bagi mahkamah dalam menjalankan kekuasaan kehakiman, terutama dalam sistem Peradilan Syariat sebagaimana yang sudah diatur. ${ }^{8}$

Aceh sebagai bagian dari Negara Kesatuan Republik Indonesia yang diberikan kewenangan untuk melaksanakan Syariat Islam, Keistimewaan dan Otonomi khusus, menjunjung tinggi kepastian hukum, keadilan dan kesamaan di depan hukum. ${ }^{9}$ Perjalanan sejarah yang panjang masyarakat Aceh selalu menjunjung tinggi ajaran Islam, dalam berbagai aspek kehidupannya. Hal ini tercermin dalam ungkapan bijak"Adat bak Poteu Meuruehom, Hukum bak Syiah kuala, Qanun bak putro pang Reusam bak Laksamana." Pelaksanaan Syariat Islam secara kaffah telah dilakukan sejak kerajaan Aceh Darussalam. Pemberlakuan syariat Islam sebagai hukum positif tidak hanya untuk kerajaan Aceh, tetapi juga beberapa kerajaan Islam lainnya di nusantara ini seperti Demak, Banten dan lain-lain. Sejak pendudukan Belanda, Syariat Islam berjalan dengan kaffah di wilayah kerajaan Aceh, karena Pemerintah Belanda menjalankan politik hukum kolonial. Tuntutan untuk melaksanakan Syariat Islam muncul kembali sejak Indonesia merdeka, lebih-lebih di era reformasi. Khususnya untuk Provinsi Daerah Istimewa Aceh kesempatan untuk melaksanakan syariat Islam didasarkan pada Undang-Undang Nomor 44 Tahun 1999 tentang penyelenggaraan keistimewaan bagi Provinsi Daerah Istimewa Aceh. ${ }^{10}$

Di daerah aceh yang digunakan ialah Hukum Acara Jinayat yaitu merupakan salah satu aturan tersendiri yang sangat diperlukan sebagaimana diamanatkan oleh Undang-Undang Nomor 44 Tahun 1999, Undang-Undang Nomor 11 Tahun 2006, dan Qanun Nomor 10 Tahun 2002, karena aturan yang ada dalam Kitab Undang-Undang Hukum Acara Pidana (KUHAP) belum sepenuhnya dapat memenuhi kebutuhan penegak hukum di Aceh. ${ }^{11}$ Maka dari itu Provinsi Aceh membuat suatu aturan yang dapat mengakomodirnya yakni mengeluarkan Qonun Aceh Nomor 7 Tahun 2013 Tentang Hukum Acara Jinayat yang berlaku di Provinsi Aceh.

Berdasarkan alasan dan latar belakang yang ada di atas, maka penulis tertarik untuk mengkaji tentang perbedaan proses penyidikan antara Kitab Undang-Undang Hukum Acara Pidana (KUHAP) atau Undang-Undang nomor 8 tahun 1981 tentang Hukum Acara Pidana Positif dengan Qonun Aceh Nomor 7 Tahun 2013 Tentang Hukum Acara Jinayat. Dengan spesifik membahas Proses Penyidikan menurut Kitab Undang-Undang Hukum Acara Pidana (KUHAP) atau Undang-Undang nomor 8 tahun 1981 tentang Hukum Acara Pidana Positif,

\footnotetext{
${ }^{8}$ Penjelasan atas Qanun Aceh Nomor 7 Tahun 2013 Tentang Hukum Acara Jinayat.

${ }^{9}$ Nur Moklis \& Agus Sanwani, Penerapan Hukum Acara Pidana/Jinayah Mahkamah Syariah Di Aceh, (Megamendung: Dipublikasikan Secara Online, 2012), 13.

${ }^{10}$ Penjelasan Atas Qanun Aceh Nomor 7 Tahun 2013 Tentang Hukum Acara Jinayat.

${ }^{11}$ Nur Moklis \& Agus Sanwani, Penerapan Hukum, 13.
} 
Proses Penyidikan menurut Qonun Aceh Nomor 7 Tahun 2013 Tentang Hukum Acara Jinayat. Perbedaan Proses Penyidikan menurut Hukum Acara Pidana Positif dan Qonun Aceh Nomor 7 Tahun 2013 Tentang Hukum Acara Jinayat.

\section{B. Metode Penelitian}

Penelitian ini merupakan penelitian hukum (legal research). Menurut F. Sugeng Istanto, penelitian hukum adalah penelitian yang diterapkan atau diberlakukan khusus pada ilmu hukum. ${ }^{12}$ Menurut jenis, sifat dan tujuannya penelitian hukum dibedakan atas penelitian hukum normatif dan penelitian hukum empiris. ${ }^{13}$ Jenis yang akan digunakan dalam penelitian ini adalah penelitian hukum normatif yuridis (yuridis normative).

Menurut Soerjono Soekanto pendekatan yuridis normatif yaitu penelitian hukum yang dilakukan dengan cara meneliti bahan pustaka atau data sekunder sebagai bahan dasar untuk diteliti dengan cara mengadakan penelusuran terhadap peraturan-peraturan dan literatur-literatur yang berkaitan dengan permasalahan yang diteliti. ${ }^{14}$ Pendekatan yuridis normatif dilakukan dengan cara menelaah dan menginterpretasikan hal-hal yang bersifat teoritis yang menyangkut asas, konsepsi, doktrin dan norma hukum yang berkaitan dengan Hukum Acara Pidana Positif dan Hukum Acara Jinayat Provinsi Aceh.

\section{Hasil dan Pembahasan \\ 1. Proses Penyidikan sesuai dengan Kitab Undang-Undang Hukum Acara Pidana (KUHAP) atau Undang-Undang nomor 8 tahun 1981 tentang Hukum Acara Pidana Positif}

Pasal 1 butir 2 (Kitab Undang-undang Hukum Acara Pidana) KUHAP menyatakan bahwa: "Penyidikan adalah serangkaian tindakan penyidik dalam hal dan menurut cara yang diatur dalam undang-undang, mencari dan mengumpulkan bukti yang dengan bukti itu membuat terang tentang tindak pidana yang terjadi dan guna menemukan tersangkanya." Berbicara mengenai penyidikan tidak lain dari membicarakan masalah pengusutan kejahatan atau pelanggaran. Penyidakan ini dilakukan oleh seorang penyidik. Adapun tugas penyidik adalah melaksanakan penyidikan, yaitu serangkaian tindakan penyidik dalam hal dan menurut cara yang diatur dalam Undang-undang Hukum Acara Pidana untuk mencari dan mengumpulkan barang bukti yang dengan bukti tersebut membuat terang tindak pidana terjadi dan guna menentukan tersangkanya. ${ }^{15}$ Di samping itu penyidik juga mempunyai tugas : 1). Membuat berita acara tentang hasil pelaksanaan tindakannya 2). Menyerahkan berkas-berkas perkara kepada Penuntut Umun atau Jaksa; penyidik dari Pegawai Negeri Sipil menyerahkannya dengan melalui penyidik dari pejabat kepolisian negara ${ }^{16}$

Selain itu adapula yang menjadi kewenangan penyidik sebagaimana termaktub di dalam Pasal 7 KUHAP yaitu, seorang penyidik mempunyai wewenang :

1. Menerima laporan atau pengaduan dari seseorang tentang adanya tindak pidana.

2. Melakukan tindakan pertama pada saat di tempat kejadian.

\footnotetext{
${ }^{12}$ F. Sugeng Istanto, Penelitian Hukum, (Yogyakarta: CV. Ganda, 2007), 29.

${ }^{13}$ Bambang Waluyo, Penelitian Hukum Dalam Praktik, (Jakarta, Sinar Grafika, 2002 ), 13.

${ }^{14}$ Soerjono Soekanto \& Sri Mamudji, Penelitian Hukum Normatif (Suatu Tinjauan Singkat), (Jakarta: Rajawali Pers, 200), 13-14.

${ }^{15}$ M. Husein Harun, Penyidik Dan Penuntut Dalam Proses Pidana, (Jakarta: PT Rineka Cipta, 1991), 123.

${ }^{16}$ Ibid., 125.
} 
3. Menyuruh berhenti seseorang tersangka dan memeriksa tanda pengenal diri.

4. Melakukan penangkapan, penahanan, penahanan, penggeledahan dan penyitaan.

5. Melakukan pemeriksaan dan penyitaan surat.

6. Mengambil sidik jari dan memotret seseorang.

7. Memanggil orang untuk didengar dan diperiksa sebagi tersangka atau saksi.

8. Mendatangkan orang ahli yang diperlukan dalam hubungannya dengan pemeriksaan perkara.

9. Mengadakan penghentikan penyidikan.

10. Mengadakan tindakan lain menurut hukum yang bertanggung jawab.

Adapun yang menjadi tujuan penyidikan adalah untuk menunjuk siapa yang telah melakukan kejahatan dan memberikan pembuktian-pembuktian mengenai masalah yang telah dilakukannya. Untuk mencapai maksud tersebut, maka penyidik akan menghimpun keterangan dengan fakta atau peristiwa-peristiwa tertentu. ${ }^{17}$ Penyidikan yang diatur dalam undang-undang ini dapat dilaksanakan setelah diketahui bahwa suatu peristiwa telah terjadi tindak pidana di mana dalam Pasal 1 butir 2 KUHAP berbunyi bahwa penyidikan adalah serangkaian tindakan penyidik mengumpulkan bukti yang dengan bukti itu membuat terang tindak pidana yang terjadi guna menemukan tersangkanya. Penyidikan dimulai sesudah terjadinya tindak pidana untuk mendapatkan keterangan-keterangan tentang:

a. Tindak pidana apa yang telah dilakukan;

b. Kapan tindak pidana itu dilakukan;

c. Dimana tindak pidana itu dilakukan;

d. Dengan apa tindak pidana itu dilakukan;

e. Bagaimana tindak pidana itu dilakukan;

f. Mengapa tindak pidana itu dilakukan;

g. Siapa pembuatnya.

Proses penyidikan tindak pidana, bahwa penyidikan meliputi $:^{18}$

a. Penyelidikan

b. Penindakan

1. Pemanggilan

2. Penangkapan

3. Penahanan

4. Penggeledahan

5. Penyitaan

c. Pemeriksaan

1. Saksi

2. Ahli

3. Tersangka

d. Penyelesaian dan penyerahan berkas perkara

${ }^{17}$ Ibid., 56.

${ }^{18}$ Himpunan bujuklak,bujuklap,bujukmin. Proses Penyidikan Tindak Pidana. (Jakarta: 1990), 24. 


\section{Pembuatan resume}

2. Penyusunan berkas perkara

3. Penyerahan berkas perkara.

Sehubungan dengan itu adapun proses penyidikan atau proses jalannya pemeriksaan penyidikan yang dirangkum dari KUHAP dan Undang-Undang Nomor 48 Tahun 2009 tentang Kekuasaan Kehakiman adalah sebagai berikut: ${ }^{19}$

a. Penyidik yang mengetahui, menerima laporan atau pengaduan tentang terjadinya suatu peristiwa yang patut diduga merupakan tindak pidana wajib segera melakukan tindakan penyidikan yang diperlukan (Pasal 106 Undang-Undang Nomor 8 Tahun 1981 tentang Kitab Undang-Undang Hukum Acara Pidana). Laporan atau pengaduan yang diajukan secara tertulis harus ditandatangani oleh pelapor atau pengadu (Pasal 108 Ayat (4) Undang-Undang Nomor 8 Tahun 1981 tentang Kitab Undang-Undang Hukum Acara Pidana). Namun apabila laporan atau pengaduan yang diajukan secara lisan harus dicatat oleh penyidik dan ditandatangani oleh pelapor atau pengadu dan penyidik (Pasal 108 Ayat (5) Undang-Undang Nomor 8 Tahun 1981 tentang Kitab Undang-Undang Hukum Acara Pidana). Setelah menerima laporan atau pengaduan, penyelidik atau penyidik harus memberikan surat tanda penerimaan laporan atau pengaduan kepada yang bersangkutan (Pasal 108 Ayat (6) UndangUndang Nomor 8 Tahun 1981 tentang Kitab UndangUndang Hukum Acara Pidana)

b. Setelah menerima penyerahan tersangka yang tertangkap tangan, penyelidik atau penyidik wajib segera melakukan pemeriksaan dan tindakan lain dalam rangka penyidikan (Pasal 111 Ayat (2) Undang-Undang Nomor 8 Tahun 1981 tentang Kitab Undang-Undang Hukum Acara Pidana)

c. Penyelidik dan penyidik yang telah menerima laporan tersebut segera datang ke tempat kejadian dapat melarang setiap orang untuk meninggalkan tempat itu selama pemeriksaan di situ belum selesai (Pasal 111 Ayat (3) Undang-Undang Nomor 8 Tahun 1981 tentang Kitab Undang-Undang Hukum Acara Pidana). Terhadap pelanggar larangan tersebut dapat dipaksa tinggal di tempat itu sampai pemeriksaan dimaksud di atas selesai (Pasal 111 Ayat (4) Undang-Undang Nomor 8 Tahun 1981 tentang Kitab UndangUndang Hukum Acara Pidana).

d. Dalam hal penyidik telah mulai melakukan penyidikan suatu peristiwa yang merupakan tindak pidana, penyidik memberitahukan hal itu kepada penuntut umum (Pasal 109 Ayat (1) Undang-Undang Nomor 8 Tahun 1981 tentang Kitab Undang-Undang Hukum Acara Pidana).

e. Apabila penyidik menghentikan penyidikan karena tidak terdapat cukup bukti atau peristiwa tersebut ternyata bukan merupakan tindak pidana atau penyidikan dihentikan demi hukum, maka penyidik memberitahukan hal itu kepada penuntut umum, tersangka atau keluarganya (Pasal 109 Ayat (2) Undang-Undang Nomor 8 Tahun 1981 tentang Kitab Undang-Undang Hukum Acara Pidana).

${ }^{19}$ Lihat Pasal 106, Pasal 109-Pasal 111 Undang-Undang Nomor 8 Tahun 1981 Tentang Hukum Acara Pidana Postif dan Undang-Undang Nomor 48 Tahun 2009 Tentang Kekuasaan Kehakiman

[53] 
f. Dalam hal penyidik telah selesai melakukan penyidikan, penyidik wajib segera menyerahkan berkas perkara itu kepada penuntut umum (Pasal 110 Ayat (1) Undang-Undang Nomor 8 Tahun 1981 tentang Kitab Undang-Undang Hukum Acara Pidana). Penyidikan dianggap telah selesai apabila dalam waktu empat belas hari penuntut umum tidak mengembalikan hasil penyidikan atau apabila sebelum batas waktu tersebut berakhir telah ada pemberitahuan tentang hal itu dari penuntut umum kepada penyidik (Pasal 110 Ayat (4) Undang-Undang Nomor 8 Tahun 1981 Tentang Kitab UndangUndang Hukum Acara Pidana).

g. Dalam melakukan penyidikan, penyidik berwenang melakukan penangkapan, penahanan, penggeledahan, penyitaan dan pemeriksaan surat dengan syarat-syarat yang ditentukan oleh undang-undang, dan mengindahkan ketentuan bahwa "tiada seorang pun yang dapat dikenakan penangkapan, penahanan, penggeledahan dan penyitaan selain atas perintah tertulis oleh kekuasaan yang sah dalam hal-hal menurut cara-cara yang diatur dengan undangundang" (Pasal 7 Undang-Undang Nomor 48 Tahun 2009 tentang Kekuasaan Kehakiman). Bahkan juga harus mengindahkan asas praduga tak bersalah (presumption of innocence), bahwa "setiap orang yang disangka, ditangkap, ditahan, dituntut dan/ atau dihadapkan di depan pengadilan wajib dianggap tidak bersalah sebelum adanya putusan pengadilan yang menyatakan kesalahannya dan memperoleh kekuatan hukum tetap" (Pasal 8 Undang-Undang Nomor 48 Tahun 2009 tentang Kekuasaan Kehakiman).

Selain dari melaksanakan fungsinya sebagai penyidikan, penyidik juga harus memperhatikan asas-asas yang menyangkut hak-hak manusia agar tidak terjadi suatu pelanggaran dalam melakukan penyidikan, adpun asas-asasnya ialah sebagai berikut:

a. Asas praduga tak bersalah yaitu setiap orang disangka, ditangkap, ditahan, dituntut dan atau diadili sidang pengadilan wajib dianggap tidak bersalah sampai adanya putusan pengadilan yang menyatakan kesalahan berdasarkan keputusan hakim yang mempunyai kekuasaan hukum yang tetap.

b. Peranan dimuka hukum yaitu perlakuan yang sama atas setiap orang dimuka hukum dengan tidak mengadakan perbedaan.

c. Hak memberi bantuan atau penasihat hukum yaitu setiap orang yang tersangkut perkara tindak pidana wajib diberikan kesempatan memperoleh bantuan hukum yang semata-mata untuk melaksanakan kepentingan pembelaan atas dirinya, sejak saat dilakukan penangkapan dan penahanan sebelum dimulainya pemeriksaan kepada tersangka wajib diberitahukan tentang apa yang disangkakan kepadanya dan haknya untuk mendapatkan bantuan hukum atau perkara itu wajib didampingi penasihat hukum.

d. Peradilan harus dilakukan dengan cepat, sederhana, terbuka, jujur, dan tidak memihak.

e. Penangkapan, penahanan, penggeledahan dan penyitaan hanya dilakukan berdasarkan perintah tertulis dari pejabat yang diberi wewenang oleh Undang-undang dan hanya dalam cara ditentukan oleh Undang-undang.

f. Tersangka yang telah ditangkap berhak untuk mendapatkan pemeriksaan dengan memberikan keterangan secara bebas dan selanjutnya untuk segera diajukan ke penuntut umum 
Seseorang yang ditangkap, ditahan, dituntut, dan diadili disidang pengadilan tanpa alasan berdasarkan undang-undang atau kekeliruan mengenai orangnya atau hukumnya dan wajib diberi ganti kerugian atau rehabilitasi. ${ }^{20}$

\section{Proses Penyidikan Menurut Qonun Aceh Nomor 7 Tahun 2013 Tentang Hukum Acara Jinayat}

Penyidikan menurut Pasal 1 Angka 21 Qonun Aceh Nomor 7 Tahun 2013 Tentang Hukum Acara Jinayat Penyidikan adalah serangkaian tindakan penyidik dalam hal dan menurut cara yang diatur dalam undang-undang dan/atau Qanun untuk mencari serta mengumpulkan bukti yang dengan bukti itu membuat terang Jarimah yang terjadi guna menemukan Tersangka.

Sehubungan dengan penjelasan di atas Undang-Undang Nomor 8 Tahun 1981 Tentang Hukum Acara Pidana (KUHAP) Pasal 1 Ayat (1) memberikan definisi tentang Penyidikan adalah serangkaian tindakan penyidik dalam hal dan menurut cara yang diatur dalam undang-undang ini untuk mencari serta mengumpulkan bukti yang dengan bukti itu membuat terang tentang tindak pidana yang terjadi dan guna menemukan tersangkanya, ayat (2) Penyidik adalah pejabat polisi negara Republik Indonesia atau pejabat pegawai negeri sipil tertentu yang diberi wewenang khusus oleh undang-undang untuk melakukan penyidikan, ayat (3) Penyidik pembantu adalah pejabat kepolisian negara Republik Indonesia yang karena diberi wewenang tertentu dapat melakukan tugas penyidikan yang diatur dalam undang-undang ini. Sedangkan untuk penyidikan dalam perkara jinayah yang menjadi kompetensi absolute mahkamah syar'iyah provinsi Nangro Aceh Darussalam adalah pejabat Polisi Nanggroe Aceh Darussalam dan pejabat Pegawai Negeri Sipil yang diberi wewenang khusus untuk melakukan penyidikan bidang Syari'at Islam. ${ }^{21}$

Merujuk kepada Pasal 15 Qanun Nomor 11 Tahun 2002 Tentang Pelaksanaan Syariat Islam Bidang Aqidah, Ibadah dan Syi'ar Islam menyatakan yang menjadi wewenang Pejabat Penyidik Pegawai Negeri Sipil ialah sebagai berikut:

a. Menerima laporan dari Wilayatul Hisbah tingkat gampong atau dari seseorang tentang adanya pelanggaran Qanun ini;

b. Melakukan tindakan pertama pada saat itu di tempat kejadian dan melakukan pemeriksaan;

c. Melakukan penyitaan benda dan atau surat;

d. Mengambil sidik jari dan memotret seseorang;

e. Memanggil orang untuk didengar dan diperiksa sebagai tersangka atau saksi;

f. Mendatangkan ahli yang diperlukan dalam hubungan dengan pemeriksaan perkara;

g. Menghentikan penyidikan bila pelanggaran tersebut tidak cukup alasan untuk diajukan ke Mahkamah Syar'iyah;

h. Mengadakan tindakan lain menurut hukum yang dapat dipertanggung jawabkan. Dalam melaksanakan tugasnya penyidik wajib menjunjung tinggi Syariat Islam dan hukum yang berlaku.

Sehubungan dengan pengertian penyidik di atas Qanun Aceh Nomor 14 Tahun 2003 tentang Khalwat (mesum) Pasal 17 juga menyebutkan pengertian dari penyidik yaitu pejabat

\footnotetext{
${ }^{20}$ Leden Marpaung, Proses Penegakan Perkara Pidana, (Jakarta : Sinar Grafika, 1992), 43.

${ }^{21}$ Nur Moklis \& Agus Sanwani, Penerapan Hukum, 107.
} 
Polisi Nanggroe Aceh Darussalam dan pejabat Pegawai Negeri Sipil yang diberi wewenang khusus untuk melakukan penyidikan bidang Syari'at Islam. Hal ini juga ditegaskan dalam Undang-Undang Nomor 11 Tahun 2006 tentang Pemerintahan Aceh bahwa penyidikan untuk penegakan syari'at Islam yang menjadi kewenangan Mahkamah Syar'iyah sepanjang mengenai jinayah dilakukan oleh Kepolisian Negara Republik Indonesia dan Penyidik Pegawai Negeri Sipil (Pasal 33 Undang-Undang Nomor 11 Tahun 2006 Tentang Pemerintah Aceh). ${ }^{22}$

Berbeda dengan KUHAP, adapun proses penyidikan yang terdapat di dalam Qonun Aceh Nomor 7 Tahun 2013 Tentang Hukum Acara Jinayat ialah tercantum dalam Pasal 110 sampai dengan Pasal 132 Qonun Aceh Nomor 7 Tahun 2013 Tentang Hukum Acara Jinayat yaitu sebagai berikut: ${ }^{23}$

Pasal 110

Penyidik yang mengetahui, menerima laporan atau pengaduan tentang terjadinya suatu peristiwa yang patut diduga merupakan Jarimah, wajib segera melakukan Penyidikan.

Pasal 111

(1). Dalam hal Penyidik telah mulai melakukan Penyidikan suatu Jarimah, Penyidik memberitahukan hal itu kepada Penuntut Umum.

(2). Dalam hal Penyidik menghentikan penyidikan karena tidak terdapat cukup bukti atau peristiwa tersebut ternyata bukan merupakan Jarimah, maka Penyidik memberitahukan hal itu kepada Penuntut Umum, Tersangka atau keluarganya.

Pasal 112

(1). Apabila penyidikan telah selesai dilakukan dan cukup alasan untuk meneruskannya, Penyidik wajib segera menyerahkan berkas perkara kepada Penuntut Umum.

(2). Penyidik PPNS selain menyerahkan hasil penyidikannya kepada Penuntut Umum, juga menyampaikan tembusannya kepada Korwas PPNS.

(3). Dalam hal Penuntut Umum mengembalikan hasil penyidikan untuk dilengkapi, Penyidik wajib segera melakukan penyidikan lanjutan sesuai dengan petunjuk Penuntut Umum.

(4). Penyidikan dianggap telah selesai, apabila dalam waktu 14 (empat belas) hari Penuntut Umum tidak mengembalikan hasil penyidikan atau apabila sebelum batas waktu tersebut berakhir telah ada pemberitahuan tentang hal itu dari penuntut umum kepada Penyidik.

Pasal 113

(1). Dalam hal tertangkap tangan:

a. setiap orang berhak menangkap Tersangka untuk segera diserahkan beserta atau tanpa barang bukti kepada Penyelidik atau Penyidik;

b. setiap orang yang mempunyai wewenang/tugas dalam bidang ketertiban, ketenteraman dan keamanan umum wajib menangkap Tersangka beserta atau tanpa barang bukti dan menyerahkan kepada Penyelidik atau Penyidik.

\footnotetext{
${ }^{22}$ Ibid.

${ }^{23}$ Pasal 109 sampai dengan Pasal 132 Qonun Aceh Nomor 7 Tahun 2013 Tentang Hukum Acara Jinayat
}

[56] 
(2). Setelah menerima penyerahan Tersangka sebagaimana dimaksud pada ayat (1) Penyelidik atau Penyidik wajib segera melakukan pemeriksaan dan tindakan lain dalam rangka penyelidikan atau penyidikan.

(3). Penyelidik atau Penyidik yang telah menerima laporan atau menerima Tersangka sebagaimana dimaksud pada ayat (2), segera datang ke tempat kejadian, dapat melarang setiap orang untuk tidak meninggalkan tempat itu selama pemeriksaan belum selesai, jika perlu dapat dilakukan upaya paksa.

Pasal 114

(1). Penyidik yang melakukan pemeriksaan, dengan menyebutkan alasan secara jelas, berwenang memanggil Tersangka dan Saksi yang dianggap perlu untuk diperiksa dengan surat panggilan yang sah dengan memperhatikan tenggang waktu yang wajar setelah ia menerima surat panggilan.

(2). Setiap orang yang dipanggil wajib datang kepada penyidik, dan jika ia tidak datang, penyidik memanggil sekali lagi, dengan perintah kepada petugas untuk membawa kepadanya.

(3). Jika seorang Tersangka atau Saksi yang dipanggil tidak dapat datang memenuhi panggilan penyidik, karena alasan yang patut dan wajar, Penyidik datang ke tempat kediamannya.

Pasal 115

(1). Sebelum pemeriksaan dimulai, penyidik wajib memberitahukan kepada Tersangka tentang haknya untuk mendapatkan bantuan hukum atau bahwa ia dalam perkaranya itu wajib didampingi oleh penasihat hukum sebagaimana dimaksud dalam Pasal 62.

(2). Pada saat Penyidik sedang melakukan pemeriksaan terhadap Tersangka, Penasihat Hukum dapat mengikuti jalannya pemeriksaan dengan cara melihat dan mendengar pemeriksaan.

Pasal 116

(1). Saksi diperiksa dengan tidak disumpah, kecuali ada cukup alasan atau diperkirakan bahwa ia tidak dapat hadir dalam pemeriksaan di sidang Mahkamah.

(2). Saksi diperiksa secara tersendiri, bila diperlukan dapat dipertemukan satu sama lain dan mereka wajib memberikan keterangan yang sebenarnya.

(3). Kepada Tersangka ditanyakan apakah ia menghendaki didengarnya Saksi yang dapat menguntungkan baginya, bila ada dicatat dalam berita acara dan Penyidik wajib memanggil dan memeriksa Saksi tersebut.

Pasal 117

(1). Keterangan atau pengakuan Tersangka dan/atau Saksi kepada penyidik diberikan tanpa tekanan dari siapapun dan/atau dalam bentuk apapun.

(2). Dalam hal Tersangka memberi keterangan atau pengakuan tentang apa yang sebenarnya telah dia lakukan sehubungan dengan Jarimah yang dipersangkakan kepadanya, Penyidik mencatat dalam berita acara secara cermat dan teliti sesuai dengan kata-kata yang diucapkan oleh Tersangka sendiri. 
(3). Penyidik harus mengingatkan tersangka untuk menyampaikan kebenaran dan tidak menyembunyikannya.

\section{Pasal 118}

(1). Keterangan atau pengakuan Tersangka dan/atau Saksi dicatat dalam berita acara yang ditandatangani oleh Penyidik dan yang bersangkutan, setelah menyetujui isinya.

(2). Berita Acara sebagaimana dimaksud pada ayat (1) diparaf setiap halamannya oleh Saksi dan/atau Tersangka.

(3). Dalam hal Tersangka dan/atau Saksi tidak bersedia membubuhkan tandatangannya, penyidik mencatat hal itu dalam berita acara dengan menyebut alasannya.

Pasal 119

Dalam hal Tersangka dan/atau Saksi yang wajib di dengar keterangannya bertempat tinggal atau berdiam di luar daerah hukum penyidik yang menjalankan penyidikan, pemeriksaan terhadap Tersangka dan/atau Saksi dapat diserahkan kepada penyidik ditempat kediaman atau tempat tinggal Tersangka dan/atau Saksi tersebut.

Pasal 120

(1). Dalam hal Penyidik menganggap perlu, ia dapat meminta pendapat ahli atau orang yang memiliki keahlian khusus.

(2). Ahli tersebut mengangkat sumpah atau mengucapkan janji di depan penyidik bahwa ia akan memberi keterangan menurut pengetahuannya yang sebenar-benarnya kecuali bila disebabkan karena harkat serta martabat, pekerjaan atau jabatannya yang mewajibkan ia menyimpan rahasia dapat menolak untuk memberikan keterangan yang diminta.

Pasal 121

Penyidik atas kekuatan sumpah jabatannya segera membuat berita acara yang diberi tanggal dan memuat Jarimah yang dipersangkakan, dengan menyebut waktu, tempat dan keadaan pada waktu Jarimah dilakukan, nama dan tempat tinggal Tersangka dan/atau Saksi, keterangan mereka, catatan mengenai akta dan/atau benda serta segala sesuatu yang dianggap perlu untuk kepentingan penyelesaian perkara.

Pasal 122

Dalam hal Tersangka ditahan dalam waktu 1 (satu) hari setelah perintah penahanan itu dijalankan, ia harus mulai diperiksa oleh Penyidik.

Pasal 123

(1). Tersangka, keluarga atau Penasihat Hukum dapat mengajukan keberatan atas Penahanan atau jenis Penahanan Tersangka kepada Penyidik yang melakukan Penahanan itu.

(2). Penyidik dapat mengabulkan permintaan sebagaimana dimaksud pada ayat (1) dengan mempertimbangkan tentang perlu atau tidaknya Tersangka itu tetap ditahan atau tetap ada dalam jenis penahanan tertentu.

(3). Apabila dalam waktu 3 (tiga) hari permintaan sebagaimana dimaksud pada ayat (1) belum dikabulkan oleh Penyidik, maka Tersangka, keluarga atau Penasihat Hukum dapat mengajukan hal itu kepada atasan Penyidik. 
(4). Atasan Penyidik dapat mengabulkan atau menolak permintaan sebagaimana dimaksud pada ayat (3) dengan mempertimbangkan masukan Penyidik tentang perlu atau tidaknya Tersangka itu tetap ditahan.

(5). Penyidik atau atasan Penyidik sebagaimana dimaksud pada ayat (3) dan ayat (4) dapat mengabulkan permintaan dengan atau tanpa syarat.

Pasal 124

Dalam hal apakah sesuatu Penahanan sah atau tidak sah menurut hukum, Tersangka, keluarga, Penasihat Hukum, atau pihak lain yang dirugikan dapat mengajukan hal itu kepada Mahkamah Syar'iyah Kabupaten/Kota setempat untuk diadakan praperadilan guna memperoleh putusan apakah penahanan atas diri Tersangka tersebut sah atau tidak sah menurut Qanun ini.

Pasal 125

Dalam hal Penyidik melakukan penggeledahan rumah terlebih dahulu menunjukkan tanda pengenal dan Surat Perintah Penggeledahan kepada Tersangka atau keluarganya, selanjutnya berlaku ketentuan sebagaimana dimaksud dalam Pasal 38, Pasal 39, dan Pasal 40.

Pasal 126

(1). Penyidik membuat berita acara tentang jalannya dan hasil penggeledahan rumah sebagaimana dimaksud dalam Pasal 39 ayat (5).

(2). Penyidik membacakan terlebih dahulu berita acara tentang penggeledahan rumah kepada yang bersangkutan, kemudian diberi tanggal dan ditandatangani oleh penyidik maupun Tersangka atau keluarganya dan/atau Keuchik atau nama lain dengan 2 (dua) orang Saksi.

(3). Dalam hal Tersangka atau keluarganya tidak bersedia membubuhkan tandatangannya, hal itu dicatat dalam berita acara dengan menyebut alasannya.

Pasal 127

(1). Untuk keamanan dan ketertiban penggeledahan rumah atau tempat tertutup lainnya, Penyidik dapat mengadakan penjagaan atau penutupan tempat yang bersangkutan.

(2). Untuk keamanan dan ketertiban penggeledahan sebagaimana dimaksud pada ayat (1), Penyidik berhak memerintahkan setiap orang yang dianggap perlu tidak meninggalkan tempat tersebut selama penggeledahan berlangsung.

Pasal 128

Dalam hal Penyidik melakukan penyitaan, terlebih dahulu ia harus menunjukkan tanda pengenalnya kepada orang dimana benda itu disita.

Pasal 129

(1). Penyidik memperlihatkan benda yang akan disita kepada orang dimana benda itu akan disita atau kepada keluarganya dan dapat meminta keterangan tentang benda yang akan disita itu dengan disaksikan oleh Keuchik atau nama lain dan/atau perangkat Gampong dengan dua orang Saksi.

(2). Penyidik membuat berita acara penyitaan yang dibacakan terlebih dahulu kepada orang dimana benda itu disita atau keluarganya dengan diberi tanggal dan ditandatangani oleh 
penyidik maupun orang atau keluarganya dan/atau Keuchik atau nama lain dan/atau perangkat Gampong dengan dua orang Saksi.

(3). Dalam hal orang dimana benda itu disita atau keluarganya tidak mau membubuhkan tanda tangannya hal itu dicatat dalam berita acara dengan menyebut alasannya.

(4). Turunan dari berita acara itu disampaikan oleh penyidik kepada atasannya, orang dimana benda itu disita atau keluarganya atau Keuchik atau nama lain dan/atau perangkat Gampong setempat.

Pasal 130

(1). Benda sitaan sebelum dibungkus, dicatat berat dan/atau jumlah menurut jenis masingmasing, ciri maupun sifat khas, tempat, hari dan tanggal penyitaan, identitas orang dimana benda itu disita dan lain-lainnya yang kemudian diberi lak atau segel dan cap jabatan dan ditandatangani oleh Penyidik.

(2). Dalam hal benda sitaan tidak mungkin dibungkus sebagaimana dimaksud pada ayat (1), Penyidik memberi catatan yang ditulis di atas label yang ditempelkan dan/atau dikaitkan pada benda tersebut.

Pasal 131

(1). Dalam hal sesuatu Jarimah sedemikian rupa sifatnya sehingga ada dugaan kuat dapat diperoleh keterangan dari berbagai surat, buku, daftar, dokumen, perangkat Informasi Teknologi (IT), dan sebagainya, penyidik segera pergi ke tempat yang dipersangkakan untuk menggeledah, memeriksa surat, buku, daftar, dokumen, perangkat Informasi Teknologi (IT), dan sebagainya, jika perlu menyitanya.

(2). Penyitaan sebagaimana dimaksud pada ayat (1) dilaksanakan menurut ketentuan sebagaimana diatur dalam Pasal 44 dan Pasal 129.

Pasal 132

(1). Dalam hal diterima pengaduan bahwa sesuatu surat atau tulisan adalah palsu atau dipalsukan atau diduga palsu oleh Penyidik maka untuk kepentingan penyidikan, oleh Penyidik dapat dimintakan keterangan mengenai hal itu dari ahli.

(2). Dalam hal timbul dugaan kuat bahwa ada surat palsu atau yang dipalsukan, Penyidik dengan surat izin ketua Mahkamah Syar'iyah Kabupaten/Kota setempat dapat datang atau dapat meminta kepada pejabat penyimpan umum yang wajib dipenuhi, supaya ia mengirimkan surat asli yang disimpannya itu kepada penyidik untuk dipergunakan sebagai bahan perbandingan.

(3). Dalam hal suatu surat yang dipandang perlu untuk pemeriksaan, menjadi bagian serta tidak dapat dipisahkan dari daftar sebagaimana dimaksud dalam Pasal 131, Penyidik dapat minta supaya daftar itu seluruhnya selama waktu yang ditentukan dalam surat permintaan dikirimkan kepadanya untuk diperiksa, dengan menyerahkan tanda penerimaan.

(4). Dalam hal surat sebagaimana dimaksud pada ayat (2) tidak menjadi bagian dari suatu daftar, penyimpan membuat salinan sebagai penggantinya sampai surat yang asli diterima 
kembali yang di bagian bawah dari salinan itu penyimpan mencatat apa sebab salinan itu dibuat.

Dalam hal surat atau daftar itu tidak dikirimkan dalam waktu yang ditentukan dalam surat permintaan, tanpa alasan yang sah, Penyidik berwenang mengambilnya.

3. Perbedaan Proses Penyidikan Menurut Hukum Acara Pidana Positif dan Qonun Aceh Nomor 7 Tahun 2013 Tentang Hukum Acara Jinayat

Dari penjelasan yang ada di atas dapat kita tarik perbedaan proses penyidikan antara hukum acara pidana positif dan hukum acara jinayat di Provinsi Aceh ialah sebagai berikut:

1. Merujuk kepada penjelasan penyidikan yang diberikan oleh kedua peraturan perundangundangan baik hukum acara pidana positif dan hukum acara jinayat bahwa penyidikan yang dilakukan oleh penyidik POLRI berkaitan dengan tindak pidana yang telah diatur oleh KUHAP sedangkan khusus penyidikan yang dilakukan oleh penyidik yang terdapat di dalam Hukum acara jinayat ialah khusus untuk melakukan penyidikan bidang Syari'at Islam. Berdasarkan hal ini, maka penyidikan yang dilakukan memiliki spesifik berkaitan dengan tindak pidana yang berbeda yang diatur oleh KUHAP menyidik tindak pidana yang bersifat umum dan khusus sesuai dengan peraturan perundang-undangan, sedangkan hukum acara jinayat penyidik hanya bisa menyidik tindak pidana yang melanggar Syari'at Islam yang diatur di dalam Al-Qur'an dan Hadist serta Hukum Jinayat yang berlaku di Provinsi Aceh.

2. Sehubungan dengan penjelasan di atas pula bahwa perbedaan yang menonjol menurut penulis ialah terkait dengan kewenangan penyidik dalam melakukan penyidikan. Di dalam KUHAP kewenangan Penyidik dalam melakukan penyidikan ialah sebagai berikut:

Pasal 7 KUHAP, seorang penyidik mempunyai wewenang :

a. Menerima laporan atau pengaduan dari seseorang tentang adanya tindak pidana.

b. Melakukan tindakan pertama pada saat di tempat kejadian.

c. Menyuruh berhenti seseorang tersangka dan memeriksa tanda pengenal diri.

d. Melakukan penangkapan, penahanan, penahanan, penggeledahan dan penyitaan.

e. Melakukan pemeriksaan dan penyitaan surat.

f. Mengambil sidik jari dan memotret seseorang.

g. Memanggil orang untuk didengar dan diperiksa sebagi tersangka atau saksi.

h. Mendatangkan orang ahli yang diperlukan dalam hubungannya dengan pemeriksaan perkara.

i. Mengadakan penghentikan penyidikan.

j. Mengadakan tindakan lain menurut hukum yang bertanggung jawab.

Sedangkan kewenangan penyidik yang diberikan oleh Pasal 15 Qanun Nomor 11 Tahun 2002 Tentang Pelaksanaan Syariat Islam Bidang Aqidah, Ibadah Dan Syi'ar Islam ialah sebagai berikut:

a. Menerima laporan dari Wilayatul Hisbah tingkat gampong atau dari seseorang tentang adanya pelanggaran Qanun ini;

b. Melakukan tindakan pertama pada saat itu di tempat kejadian dan melakukan pemeriksaan;

c. Melakukan penyitaan benda dan atau surat; 
d. Mengambil sidik jari dan memotret seseorang;

e. Memanggil orang untuk didengar dan diperiksa sebagai tersangka atau saksi;

f. Mendatangkan ahli yang diperlukan dalam hubungan dengan pemeriksaan perkara;

g. Menghentikan penyidikan bila pelanggaran tersebut tidak cukup alasan untuk diajukan ke Mahkamah Syar'iyah;

h. Mengadakan tindakan lain menurut hukum yang dapat dipertanggung jawabkan. Dalam melaksanakan tugasnya penyidik wajib menjunjung tinggi Syariat Islam dan hukum yang berlaku.

Selanjutnya yang terahir menurut penulis yang menjadi pembeda pada saat proses penyidikan di dalam KUHAP dan Hukum Acara Jinayat Provinsi Aceh ialah terkait dengan alur melakukan penyidikan terhadap suatu tindak pidana/jarimah tentang dalam hal sesuatu Jarimah sedemikian rupa sifatnya sehingga ada dugaan kuat dapat diperoleh keterangan dari berbagai surat, buku, daftar, dokumen, perangkat Informasi Teknologi (IT), dan sebagainya, penyidik segera pergi ke tempat yang dipersangkakan untuk menggeledah, memeriksa surat, buku, daftar, dokumen, perangkat Informasi Teknologi (IT), dan sebagainya, jika perlu menyitanya. Sedangkan di dalam Hukum Acara pidana Positif belum diatur secara omprehensif seperti yang tertera di dalam Hukum Acara Jinayat.

\section{Penutup}

Dari hasil penelitian penulis yang diuraikan di atas, maka sampailah penulis kepada kesimpulan yaitu sebagai berikut:

1. Bahwa proses Penyidikan yang tercantum di dalam Undang-undang Nomor 8 Tahun 1981 Tentang KUHAP ialah mulai dari:

a. Penyelidikan.

b. Penindakan/:

1. Pemanggilan

2. Penangkapan

3. Penahanan

4. Penggeledahan

5. Penyitaan

c. Pemeriksaan

1. Saksi

2. Ahli

3. tersangka

d. Penyelesaian dan penyerahan berkas perkara

1. Pembuatan resume

2. penyusuna berkas perkara

3. penyerahan berkas perkara.

2. Bahwa proses Penyidikan yang tercatum di dalam Undang-undang Nomor 7 Tahun 2013 Tentang Hukum Acara Jinayat ialah tercantum di dalam Pasal 110 sampai dengan Pasal 132. 
3. Adapun terkait Perbedaan Proses Penyidikan menurut Hukum Acara Pidana Positif dan Qanun Aceh Nomor 7 Tahun 2013 Tentang Hukum Acara Jinayat ialah (1) terkait tentang paradigma penjelasan penyidikan yang diatur berbeda, (2) terkait tentang wewenang penyidik dan (3) terkait dengan penyidikan langsung tindak pidana/jarimah.

\section{DAFTAR PUSTAKA}

Hamzah Andi, Hukum Acara Pidana Indonesia, Jakarta: Sinar Grafika, 2001.

Effendi Tolib, Dasar-Dasar Hukum Acara Pidana Perkembangan dan Pembaharuan, Malang: Setara Press, 2014.

Naskah Akademik Rancangan Undang-Undang Hukum Acara Pidana Tahun 2010.

O.S. hieariej Eddy, Pengantar Hukum Acara Pidana, (Jakarta: Modul I Materi Kuliah Prodi Hukum Universitas Terbuka.

Soesilo R, Hukum Acara Pidana (Prosedur Penyelesaian Perkara Pidana menurut KUHAP bagi penegak Hukum), (Jakarta: Politeria, 1982.

Penjelasan atas Qanun Aceh Nomor 7 Tahun 2013 Tentang Hukum Acara Jinayat.

Moklis Nur \& Sanwani Agus, Penerapan Hukum Acara Pidana/Jinayah Mahkamah Syariah Di Aceh, Megamendung: Dipublikasikan Secara Online, 2012

Penjelasan Atas Qanun Aceh Nomor 7 Tahun 2013 Tentang Hukum Acara Jinayat.

Sugeng Istanto F., Penelitian Hukum, Yogyakarta: CV. Ganda, 2007

Waluyo Bambang, Penelitian Hukum dalam Praktik, Jakarta, Sinar Grafika, 2002

Soekanto Soerjono \& Mamudji Sri, Penelitian Hukum Normatif (Suatu Tinjauan Singkat), Jakarta: Rajawali Pers, 2006

Harun M. Husein, Penyidik Dan Penuntut Dalam Proses Pidana, Jakarta: PT Rineka Cipta, 1991 Himpunan bujuklak,bujuklap,bujukmin, Proses Penyidikan Tindak Pidana. Jakarta: 1990 Undang-Undang Nomor 8 Tahun 1981 Tentang Hukum Acara Pidana Postif Undang-Undang Nomor 48 Tahun 2009 Tentang Kekuasaan Kehakiman Leden Marpaung, Proses Penegakan Perkara Pidana, (Jakarta : Sinar Grafika, 1992 Qonun Aceh Nomor 7 Tahun 2013 Tentang Hukum Acara Jinayat 